\title{
Distribution and abundance of benthic microalgae in a shallow southwestern Australian estuarine system
}

\author{
R. J. Lukatelich \& A. J. McComb \\ Centre for Water Research and Botany Department, University of Western Australia, Nedlands, Western Australia 6009, \\ Australia
}

\begin{abstract}
Measurements were made of benthic microalgal biomass (chlorophyll $\mathrm{mg} \mathrm{m}^{-2}$ ) and concentration (chlorophyll, $\mu \mathrm{g} \mathrm{g}^{-1}$ dry weight of sediment) from the Peel-Harvey estuarine system, Western Australia. Most chlorophyll was in the top $1 \mathrm{~cm}$ of sediment, and less than $10 \%$ of chlorophyll a was non-functional as determined by hexane extraction. Highest biomass occurred at shallow sites and on coarse sandy sediments. Biomass was higher in Harvey $\left(202 \mathrm{mg} \mathrm{m}^{-2}\right)$ than Peel $\left(107 \mathrm{mg} \mathrm{m}^{-2}\right)$ in summer when there was a large population of macroalgae in Peel; biomass was similar in winter (Harvey $163 \mathrm{mg} \mathrm{m}^{-2}$. Peel $151 \mathrm{mg} \mathrm{m}^{-2}$ ). Biomass increased with the onset of riverine nutrient input and decreased when blooms occurred in the water column. Except during Nodularia blooms, the biomass (chlorophyll) of benthic microalgae greatly exceeded (e.g. 40 times) the biomass of chlorophyll in the water column above. In summer much of the chlorophyll of the water column was due to wind stirring of benthic microalgae. The possible importance of benthic microalgae to the productivity of shallow systems is emphasized.
\end{abstract}

\section{INTRODUCTION}

The morphometric and hydrologic properties of aquatic ecosystems are important in determining the relative contributions of the different producer components of an ecosystem. In shallow aquatic ecosystems, or those with large intertidal regions, benthic microalgae are often important contributors to primary production. For example, in the Wadden Sea (Grontved 1962, Cadée \& Hegeman 1974, Colijn 1978, Cadée 1980), Marion Lake, Canada (Hargrave 1969, Gruendling 1971), Ythan Estuary, Scotland (Leach 1970), Lake Wabamun, Canada (Hickman 1974), and the Chukchi Sea, Alaska (Matheke \& Horner 1974) the importance of benthic microalgal production to total system production has been shown. Their production may often exceed that of phytoplankton and macroalgae in many shallow systems (Taasen \& Hoisaeter 1981).

The benthic microalgal community has been largely ignored in studies in shallow or intertidal systems in Australia, and the purpose of this study was to examine the abundance and distribution of benthic microalgae in the Peel-Harvey estuarine system, a large $\left(133 \mathrm{~km}^{2}\right)$, shallow $(<2.5 \mathrm{~m})$ estuarine system in southwestern Australia. The biomass and productivity of phytoplankton are known to be high in this system (McComb et al. 1981), and the emphasis in the work described here has been placed on determining the biomass of benthic microalgae relative to the phytoplankton, a background for assessing the need for productivity studies in the future. The possible roles of several chemical and physical factors in controlling benthic microalgal biomass were also investigated.

\section{STUDY AREA}

The Peel-Harvey estuarine system, located $80 \mathrm{~km}$ south of Perth, Western Australia, consists of 2 large interconnected coastal plain lagoons with a narrow channel, $5 \mathrm{~km}$ long, connecting it to the ocean (Fig. 1). Peel Inlet is a nearly circular basin of $75 \mathrm{~km}^{2}$ with wide peripheral platforms $(<0.5 \mathrm{~m})$ which occupy more than half the total area. The deepest portions of Peel Inlet are just over $2.0 \mathrm{~m}$. Harvey Estuary, $56 \mathrm{~km}^{2}$, is a $20 \mathrm{~km}$ long lagoon in an inter-dune depression, reaching $2.5 \mathrm{~m}$ depth in its central basin. Both estuaries are of 
similar volume: Peel Inlet $61 \times 10^{6} \mathrm{~m}^{3}$ and Harvey Estuary $56 \times 10^{6} \mathrm{~m}^{3}$.

The astronomic tidal amplitude in the Peel-Harvey system is usually less than $10 \mathrm{~cm}$, with a maximum daily range of $20 \mathrm{~cm}$, whereas the variation in water level caused by long-term changes in sea-level can range up to $50 \mathrm{~cm}$ over a 5 to $15 \mathrm{~d}$ period.

The area has a Mediterranean-type climate with strongly seasonal rainfall and riverflow, $90 \%$ occurring in the 4 winter months from June to September. Three rivers feed the system; the Murray, in an average year, contributes $51 \%$ of the total flow ( $\left.560 \times 10^{6} \mathrm{~m}^{3}\right)$; the Serpentine, which has been dammed, contributes $12 \%$ of total flow; and the Harvey, whose upper reaches have also been dammed, contributes $37 \%$ of total flow (Hodgkin et al. 1981). Salinity is closely linked to river-flow, and ranges from $2 \%$ in winter to $50 \%$ in mid-autumn. Water temperatures range from $12{ }^{\circ} \mathrm{C}$ in winter to about $28^{\circ} \mathrm{C}$ in summer.

Due to clearing and increased fertilizer application rates in the catchment areas since the 1950's the system has become eutrophic (Hodgkin et al. 1981, McComb et al, 1981, Birch 1982, McComb 1982). Increased algal production manifests itself differently

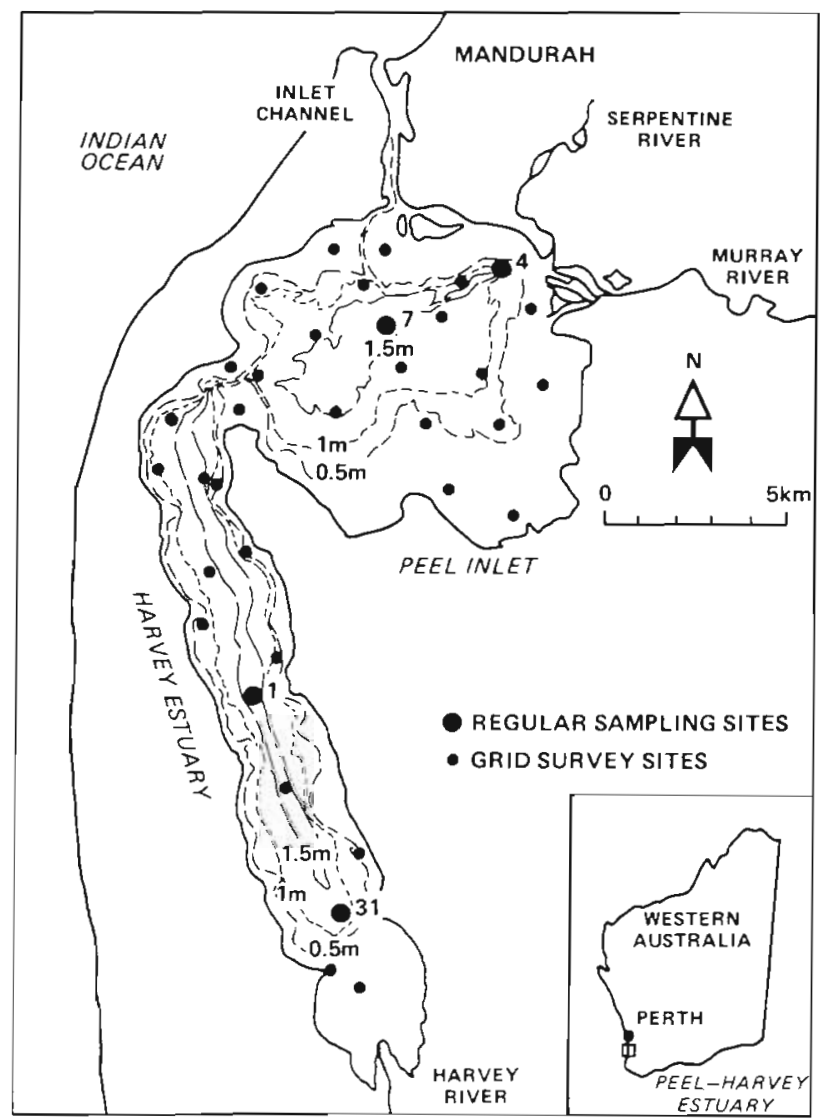

Fig. 1 The Peel-Harvey Estuarine System showing the location of the sampling sites. The $0.5 \mathrm{~m}, 1.0 \mathrm{~m}$ and $1.5 \mathrm{~m}$ contours are shown. Insert shows location of the system in the 2 estuaries. Peel Inlet has been affected by massive growths of macroalgae, in particular Cladophora and Chaetomorpha, while the Harvey Estuary has supported dense summer blooms of the blue-green alga Nodularia spumigena following the collapse of winter diatom blooms. Macroalgae are sparse in Harvey Estuary.

The morphology, hydrology and ecology of the system are discussed in detail by Hodgkin et al. (1981) and Hodgkin \& Lenanton (1981); in its general features of seasonal salinity changes, shallow basin and restricted exchange with the ocean the Peel-Harvey system is typical of a series of estuaries in southwestern Australia.

\section{MATERIALS AND METHODS}

Sampling. Samples were collected at 4 sites in the system (Fig. 1) at fortnightly intervals. Information from these regular sites was supplemented by 2 intensive sampling surveys (grid surveys) carried out at 36 sites (Fig. 1) on 30 March 1979 and 14 September 1979.

'Surface' water samples were collected approximately $10 \mathrm{~cm}$ below the surface using a 11 polyethylene bottle, and depth samples with a submersible electric pump (Rule 1750, Rule Industries, Massachusetts, USA). Samples were stored on ice in the field, using $150 \mathrm{ml}$ sealable polyethylene bags (Whirlpak, NASCO, Kansas, USA), and frozen on return to the laboratory.

Water samples for chlorophyll a analysis were collected in 11 polyethylene bottles, stored on ice, filtered through GFC-filter papers (pore size $1.2 \mu \mathrm{m}$, Whatman Ltd., England) within $24 \mathrm{~h}$ of collection and frozen.

Sediment samples were collected using a $64 \mathrm{~mm}$ diameter Perspex corer, by diving. Two core samples were taken, and each was subsampled for sediment chlorophyll analysis by pushing the mouth of a No. 16 Duranol vial $8.8 \mathrm{~cm}^{2}$ (Duranol Plastics Pty. Ltd., Melbourne, Australia), which had a small hole drilled in the bottom, down into each sediment core. The vials were immediately placed on ice and frozen on return to the laboratory.

Chlorophyll a analysis. Microalgal biomass was measured as concentration of chlorophyll $a$. The frozen filters from the water samples were ground, extracted in $90 \%$ acetone, and chlorophyll measured spectrophotometrically (Varian 634S Spectrophotometer, Varian Techtron, Springvale, Australia), using the methods of Strickland \& Parsons (1972).

Sediment chlorophyll analysis was carried out on the top $10 \mathrm{~mm}$ of the frozen core. The sediment was ground in a mortar for $60 \mathrm{~s}$ and acetone added. Moisture content was used to adjust the amount of absolute 
solvent needed to bring the solvent concentration to $90 \%(\mathrm{v} / \mathrm{v})$ acetone. The sediment suspension was placed in a screw cap glass jar and left to extract in the dark for 24 h at $4{ }^{\circ} \mathrm{C}$. A subsample $(8 \mathrm{ml})$ was removed and centrifuged for $8 \mathrm{~min}$ at $3500 \mathrm{rpm}$ to settle any particulate material. Chlorophyll a determinations were made following the methods outlined above. The sediment was dried at $105^{\circ} \mathrm{C}$ for $24 \mathrm{~h}$. Results are expressed as the concentration of chlorophyll per unit area, or per gram dry weight of sediment. The vertical distribution of chlorophyll in the surface sediment was determined by measuring the chlorophyll content of $1 \mathrm{~cm}$ sediment slices.

The variability of the chlorophyll concentration of the surface sediment was determined on 1 occasion. The chlorophyll content of 20 different samples from each of the 4 regular sampling sites showed a mean coefficient of variation of $26.7 \%$. Reported literature values average $20.8 \%$ (Taasen \& Hoisaeter 1981).

Hexane extractions were performed on bulked acetone extracts from each site to determine the fraction of functional chlorophyll a present in the surface sediment, following the methods of Whitney \& Darley (1979).

Physical and chemical variables. Selected physical and chemical characteristics of the water column were monitored concurrently with the sediment sampling. Temperature and salinity were recorded using an Auto-Lab Portable Salinity-Temperature Meter (Model 602. Hamon, Autolab, Sydney) calibrated with standard seawater (Standard Seawater Service, Charlottenlund, Denmark).

Secchi disc readings were taken on the unshaded side of the boat with a $20 \mathrm{~cm}$ diameter disc painted with black and white quadrants. Light attenuation was estimated from Secchi depth. The relation between the natural logarithm of attenuation coefficient, measured with an underwater light sensor (Licor, Lambda Instrument Corp., Nebraska, USA), and the natural logarithm of Secchi depth was significant both for Peel Inlet $(\mathrm{r}=-0.814 ; \mathrm{n}=44)$ and Harvey Estuary $(r=-0.902 ; n=45)$. When the Secchi disc depth was less than the water depth, the attenuation coefficient was calculated from the regression equation for the relevant estuary.

Total turbidity was determined by measuring the absorbance of an unfiltered water sample at $440 \mathrm{~nm}$ (Varian 634S Spectrophotometer).

Ammonium-nitrogen was measured on unfiltered water samples by the isocyanurate method (Dal Pont et al. 1974). Nitrate plus nitrite-nitrogen was determined after copper-cadmium reduction with a Technicon Autoanalyser II (Technicon Industrial Systems, Tarrytown, New York).

Organic nitrogen was determined by Kjeldahl diges- tion (concentrated sulphuric acid in the presence of a mercury catalyst, Anonymous 1971) using a programmable block digester (Windrift Instuments Welshpool, Australia). The resulting total ammonia was then determined using the autoanalyser (Technicon Industrial method 376-75 W/B). The free ammonia concentration of the sample was then subtracted from the total ammonia concentration to give 'organic' nitrogen.

Orthophosphate was measured colorimetrically by the single solution molybdenum blue method (Major et al. 1972). These samples were filtered in the field through $0.45 \mu \mathrm{m}$ filters (Millipore Corp., Massachusetts, USA). Total phosphorus was measured by digestion of water samples with a 1:1 mixture of concentrated nitric and perchloric acid and analysis of the resulting total orthophosphate using the single solution method (Anonymous 1971, Major et al. 1972, McGlynn 1974). 'Organic' phosphorus was calculated from the difference between total phosphorus and orthophosphate present in undigested samples.

The physical and chemical characteristics of the surface (top $2 \mathrm{~cm}$ ) sediment were also monitored during the sampling period and have been reported by Gabrielson (1981) and Gabrielson \& Lukatelich (1985).

Calculations. Linear correlations, Students' T-tests, and stepwise multiple regressions were performed using SPSS programmes (Nie et al. 1975). Mapping was done using a SYMAP programme (Dougenik \& Sheehan 1977).

Total water column and sediment chlorophyll a loads were estimated from planimetry of computer drawn maps of the amount expressed per unit area. A digitizer (Model 2000, Summagraphics Corp.) was used to measure the area of each size class interval.

\section{RESULTS AND DISCUSSION}

\section{Functional chlorophyll a}

The chlorophyll a concentration of the surface sediment is often used to estimate the standing crop of benthic microalgae (Steele \& Baird 1968, Leach 1970 , Fenchel \& Straarup 1971, Bunt et al. 1972, Cadée \& Hegeman 1974, 1977, Estrada et al. 1974, Matheke \& Horner 1974, Joint 1978, Colijn \& Dijkema 1981, Davis \& Lee 1983, Colijn \& de Jonge 1984). Traditional methods of measuring functional chlorophyll $a$ also measure chlorophyll a degradation products which absorb at the same wavelengths. These degradation products may be abundant in sediments and can lead to overestimates of functional chlorophyll a concentration (Whitney \& Darley 1979, Heffernan \& Gibson 1983). Partitioning of acetone extracts with hexane 
removes degradation products which lack the phytol chain (e.g. chlorophyllides and phaeophorbides) and which would otherwise be measured as chlorophyll a (Whitney \& Darley 1979).

The concentration of chlorophyll $a$ in acetone extracts before and after hexane partitioning for each site is shown in Table 1 . The results are directly comparable because hexane partitioning was carried out

Table 1 Comparison of acetone and hexane chlorophyll a determinations. Pigment concentrations in $\mathrm{mg}$ per acetone extract

\begin{tabular}{|ccc|}
\hline Station & Acetone & Hexane \\
\hline 1 & 1.65 & 1.51 \\
4 & 1.17 & 1.16 \\
7 & 1.81 & 1.65 \\
31 & 6.48 & 6.15 \\
\hline
\end{tabular}

STATION 1

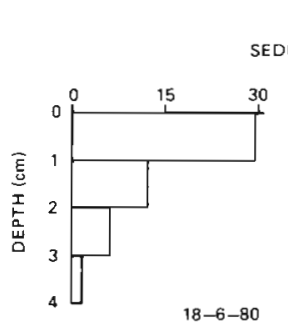

SEDIMENT CHLOROPHYLL a $\psi \mu \mathrm{g} / \mathrm{g}$ drY we?
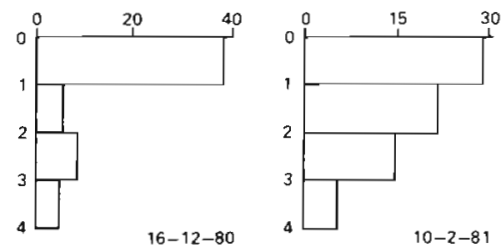

STATION 4
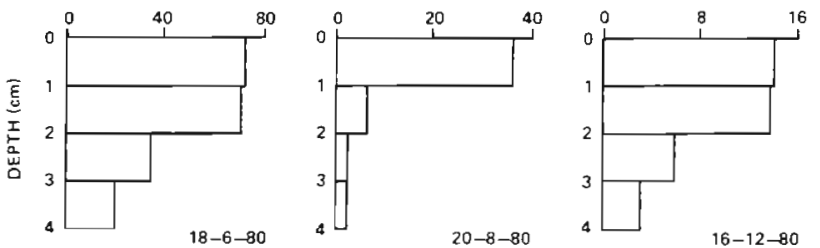

STATION 7
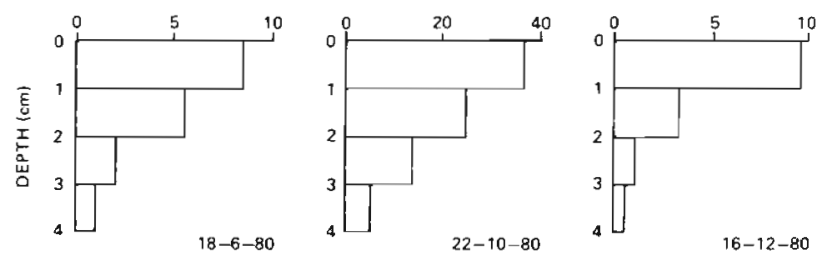

STATION 31
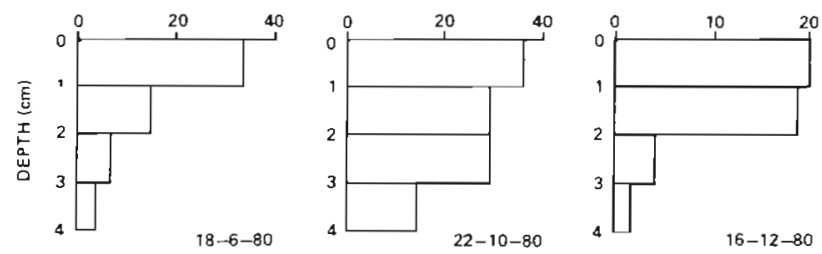

Fig. 2. Depth distribution of chlorophyll $a$ in the top $4 \mathrm{~cm}$ of sediment on a subsample from the acetone extract. The decrease in chlorophyll a concentration after hexane partitioning was less than $10 \%$ at all sites. Thus most of the chlorophyll a (>90\%) in these sediments was presumably functional chlorophyll $a$ and may represent photosynthetic cells. In view of the small difference in the chlorophyll a concentration of the acetone and hexane extracts, no correction factor was applied to the chlorophyll a estimates in this study.

\section{Vertical distribution of chlorophyll $a$}

As with many previous studies (Grøntved 1965, Pamatmat 1968, Steele \& Baird 1968, Leach 1970, Fenchel \& Straarup 1971, Cadée \& Hegeman 1974) considerable amounts of chlorophyll a were found at depths below the sediment photic zone. In sediments the limit of the photic zone is generally from 2 to $5 \mathrm{~mm}$ depending on sediment type and microalgal biomass (Fenchel \& Straarup 1971). The vertical distribution of chlorophyll a was determined on 3 occasions at each of the regular sampling sites (Fig. 2). Maximum concentrations of chlorophyll a were always found in the top centimetre of sediment and on most occasions there was a marked drop in chlorophyll a concentration with depth.

The top $2 \mathrm{~cm}$ of sediment contained on average $80 \%$ of the chlorophyll $a$ of the 0 to $4 \mathrm{~cm}$ layer. The proportion of chlorophyll a accounted for by degradation products ( $<10 \%$ in the top $\mathrm{cm}_{\text {, }}$ see above) is likely to increase with depth below the photic zone, though this was not determined here. So the proportion of functional chlorophyll a contained in the top $2 \mathrm{~cm}$ is probably greater than $80 \%$.

Reworking of the sediments by wave action and animals probably causes the distribution of benthic microalgae in the deeper layers of the sediment, though Cadée \& Hegeman (1974) demonstrated that active migration may also take place. Benthic microalgae sampled from the sediment below the photic zone have been found to be photosynthetic when exposed to light (Grøntved 1962, Steele \& Baird 1968, Hunding 1971, Cadée \& Hegeman 1974), and hence constitute an important stock of potential primary producers.

\section{Spatial distribution}

The spatial distribution of the concentration of chlorophyll $a$ in the top $1 \mathrm{~cm}$ of sediment in the PeelHarvey system was mapped on 2 occasions. The results of the summer survey are shown in Fig. 3a. Sediment chlorophyll concentrations were much higher in the Harvey $\left(\right.$ mean $\left.=202 \mathrm{mg} \mathrm{m}^{-2}\right)$ than in the Peel $(107.2$ 

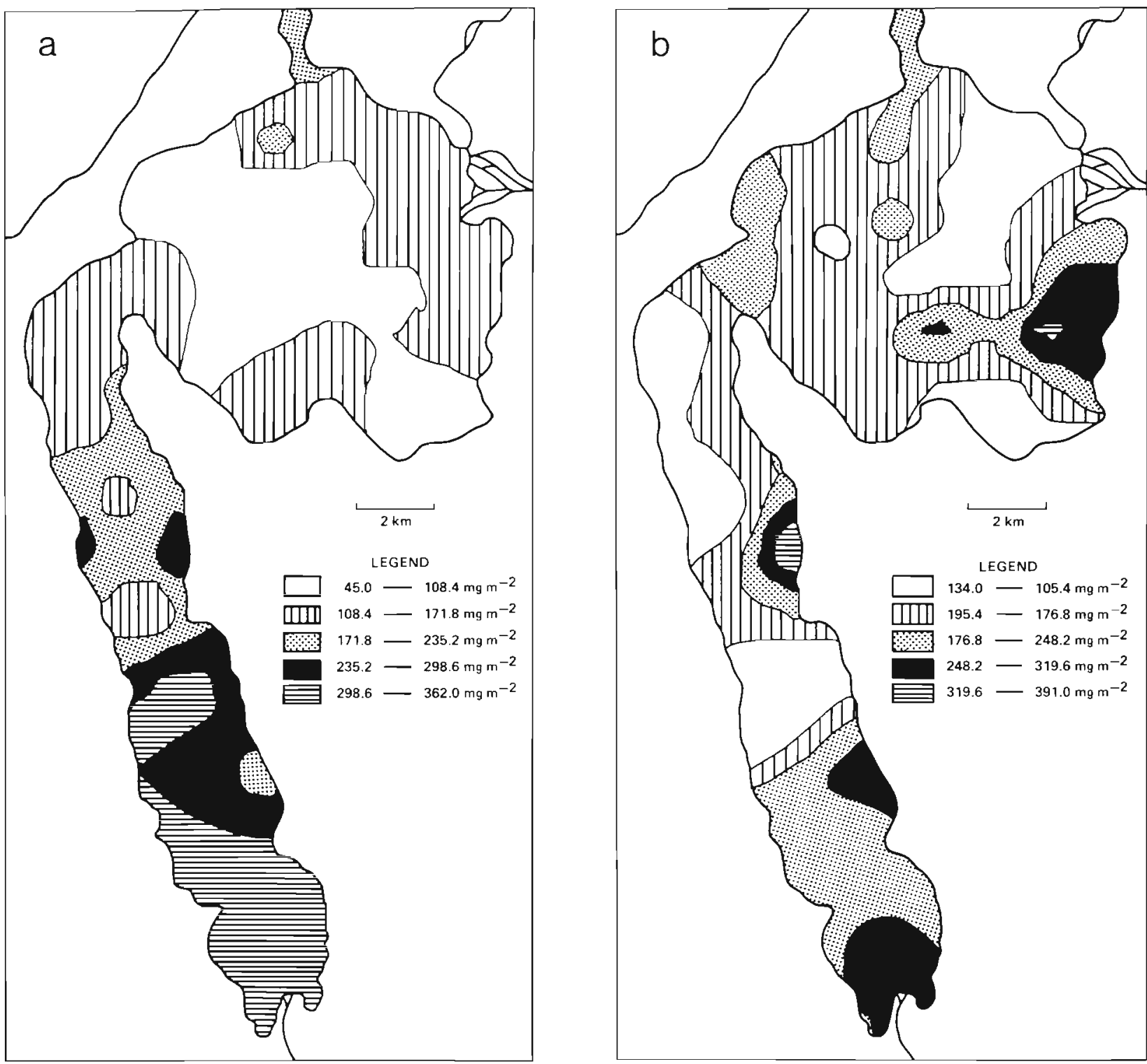

Fig. 3. Distribution of sediment chlorophyll $a$ in the Peel-Harvey system on (a) 30 March 1979, (b) 14 September 1979

$\mathrm{mg} \mathrm{m}^{-2}$ ). At the time, Peel Inlet supported a massive biomass of macroalgae $(>60,000$ tonnes dry weight: Gordon et al. 1981) which covered most of the floor of the estuary, severely restricting light penetration to the surface sediment. For example, a $1 \mathrm{~cm}$ thick bed of Cladophora montagnaena (the dominant macroalga at the time) reduces incident PAR by $99 \%$ of that reaching the surface of the bed (Gordon et al. 1981). In the winter survey (Fig. 3b) the levels were similar in both estuaries $\left(\right.$ mean $=162.8 \mathrm{mg} \mathrm{m}^{-2}$ Harvey, $151.2 \mathrm{mg}$ $\mathrm{m}^{-2}$ Peel), and the macroalgal biomass in Peel Inlet was substantially less $(<10,000$ tonnes, Gordon et al. 1981). On both occasions the highest concentrations of sediment chlorophyll were recorded at the shallower sites; most of the central basin of the Peel and to a lesser extent the Harvey had low concentrations of sediment chlorophyll.

Independent linear correlations between sediment chlorophyll concentration and the other measured variables were sought, to help indicate which factors might be important in determining the spatial distribution of sediment chlorophyll. The correlations for both surveys are given in Table 2 , where the variables are arranged in order of decreasing correlation. In the summer survey the sediment chlorophyll concentration was significantly, positively correlated with the ammonium, nitrate and organic nitrogen concentrations in the water column; also with organic phosphorus concentration and salinity. As noted above, sediment chlorophyll concentrations were much 
Table 2. Correlations between sediment chlorophyll a concentration and environmental variables. Variables are arranged in order of decreasing correlation, with a break at $p$ $>0.05$. CHL: Chlorophyll a ( g l $\left.^{-1}\right)$; DEPTH: depth $(\mathrm{m})$; EXT.N: sediment extractable nitrogen $\left(\mathrm{mg} \mathrm{m}^{-2}\right)_{\text {; }}$ EXT $\mathrm{PO}_{4}$ : sediment extractable phosphate $\left(\mathrm{mg} \mathrm{m} \mathrm{m}^{-2}\right)_{i} \mathrm{NH}_{4}$ : ammonium nitrogen $\left(\mu \mathrm{gl}^{-1}\right) ; \mathrm{NO}_{3}$ : nitrate-nitrite nitrogen $\left(\mu \mathrm{gl}^{-1}\right)$; ORG $\mathrm{N}$ :

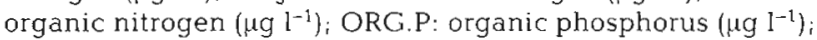
$\mathrm{PO}_{4}$ : phosphate phosphorus (ug $\left.\mathrm{l}^{-1}\right)$; SALT: salinity (\%o); SED.TN: sediment total nitrogen $\left(\mathrm{g} \mathrm{m}^{-2}\right)_{\text {i }}$ SED.TP: sediment total phosphorus $\left(\mathrm{g} \mathrm{m}^{-2}\right)_{i}$ TURB: turbidity; W/D: wet/dry sediment ratio; \% ORG: sediment organic matter content $(\%) ;(-)$ : negative correlation

\begin{tabular}{|c|c|c|c|}
\hline \multicolumn{2}{|c|}{$\operatorname{March}(\mathrm{n}=34)$} & \multicolumn{2}{|c|}{ September $(n=36)$} \\
\hline Variable & $\mathrm{P}$ & Variable & $\mathrm{P}$ \\
\hline $\mathrm{NH}_{4}$ & $<0.001$ & $\%$ ORG (-) & 0.018 \\
\hline $\mathrm{NO}_{3}$ & $<0.001$ & W/D $(-)$ & 0.021 \\
\hline ORG.N & $<0.001$ & DEPTH (-) & 0.046 \\
\hline SALT & $<0.001$ & & \\
\hline ORG.P & 0.012 & & \\
\hline W/D (-) & 0.022 & $\begin{array}{l}\text { ORGiP } \\
\text { SALT (-) }\end{array}$ & $\begin{array}{l}0.108 \\
0.172\end{array}$ \\
\hline$\%$ ORG $(-)$ & 0.028 & $\begin{array}{l}\text { SALI (-) } \\
\text { TURB }\end{array}$ & $\begin{array}{l}0.172 \\
0.218\end{array}$ \\
\hline \multirow[t]{2}{*}{ DEPTH $(-)$} & 0.029 & $\begin{array}{l}\text { 1URB } \\
\mathrm{PO}_{4}\end{array}$ & $\begin{array}{l}0.218 \\
0.298\end{array}$ \\
\hline & & CHL & 0.303 \\
\hline EXT.N & 0.103 & SED.TP & 0.391 \\
\hline SED.TN (-) & 0.131 & $\mathrm{NO}_{3}(-)$ & 0.563 \\
\hline TURB & 0.638 & $\mathrm{NH}_{4}$ & 0.586 \\
\hline $\mathrm{PO}_{4}(-)$ & 0.824 & EXT.N & 0.664 \\
\hline EXT. $\mathrm{PO}_{4}(-)$ & 0.955 & SED.TN $(-)$ & 0.669 \\
\hline CHL $(-)$ & 0.961 & EXT. $\mathrm{PO}_{4}$ & 0.726 \\
\hline SED.TP & 0.976 & ORG.N & 0.826 \\
\hline
\end{tabular}

higher in the Harvey in the summer survey, as were all of the above variables. When the Harvey data were analysed separately, there were no significant correlations between sediment chlorophyll concentration and any of these variables as the range of values encountered in the Harvey data alone was much smaller than when the Peel data were included.

Sediment chlorophyll concentration was significantly, negatively correlated with water depth, and the organic matter and water content (wet/dry ratio) of the sediment on both occasions. The correlations were also significant when the data for each estuary were analysed separately. No significant correlations were recorded with the nutrient ( $\mathrm{N}$ and $\mathrm{P}$ ) content of the surface sediment in either survey. This suggests that $\mathrm{N}$ and $\mathrm{P}$ availability may not be important in determining the spatial distribution of sediment chlorophyll in the Peel-Harvey system at a particular time. Admiraal (1980) concluded that the biomass of benthic diatom populations in the Eems-Dollard estuary was not nitrogen or phosphorus limited. The characteristics of the water above the sediment surface, apart from depth, also seem to be of minor importance in determining the distribution of sediment chlorophyll in the Peel-Harvey system. Gruendling (1971) found that the concen- tration of nutrients in the water immediately above the sediment surface were not important in controlling the biomass of benthic microalgae.

The water depth and the characteristics of the surface sediment were highly intercorrelated. The surface sediments on the shallow marginal shelf in Peel Inlet and the shallow margins of Harvey Estuary are a relatively coarse sand with a low organic and water content. The surface sediments in the central basin of Peel Inlet are fine, silty sands, while those in the deeper $(>1.5 \mathrm{~m})$ portions of the Harvey are fine, silty muds.

The sediment type and depth of water above the sediment surface determine the depth of the sediment photic zone. Light penetration decreases with decreasing sediment particle size (Gomoiu 1967). Riznyk \& Phinney (1972) found that sediment grain size was an important factor in determining benthic microalgal production, and Admiraal (1980) has emphasized that irradiance level may be important in determining the spatial distribution of benthic microalgae. Davis \& McIntire (1983) found that the spatial patterns of sediment chlorophyll a were associated with sediment type in Netarts Bay, Oregon. Of the variables measured in the Peel-Harvey system, the spatial distribution of sediment chlorophyll appears to be largely determined by the sediment type and depth of water above the sediment surface, which interact to determine the depth of the sediment photic zone.

\section{Seasonal fluctuations}

Most benthic microalgal studies from shallow or intertidal systems have found seasonal fluctuations in standing crop (Grøntved 1960, 1962, Round 1960, Gargas 1970, Leach 1970, Gruendling 1971, Joint 1978 van den Hoek et al. 1979, Colijn \& Dijkema 1981), while others have found no seasonal fluctuations (Pamatmat 1968, Steele \& Baird 1968, Riznyk \& Phinney 1972, Cadée \& Hegeman 1974, Riznyk et al. 1978) Both situations were encountered in the results of the present study.

The sediment chlorophyll concentration, at both the Harvey sites (Stn 1 and 31), was fairly stable during the summer-autumn period of 1979/80 (Fig. 4). Concentrations at both sites began to increase in late autumn, well before the initiation of the winter-early spring diatom bloom in the water column (Fig. 4). The sediment bloom collapsed with the onset of the water column diatom bloom, and peaked again after the collapse of that bloom. With the onset of the Nodularia bloom the sediment chlorophyll concentration again fell. Nodularia did not bloom during the summer of 1979/80.

The marked increase in the sediment chlorophyll 


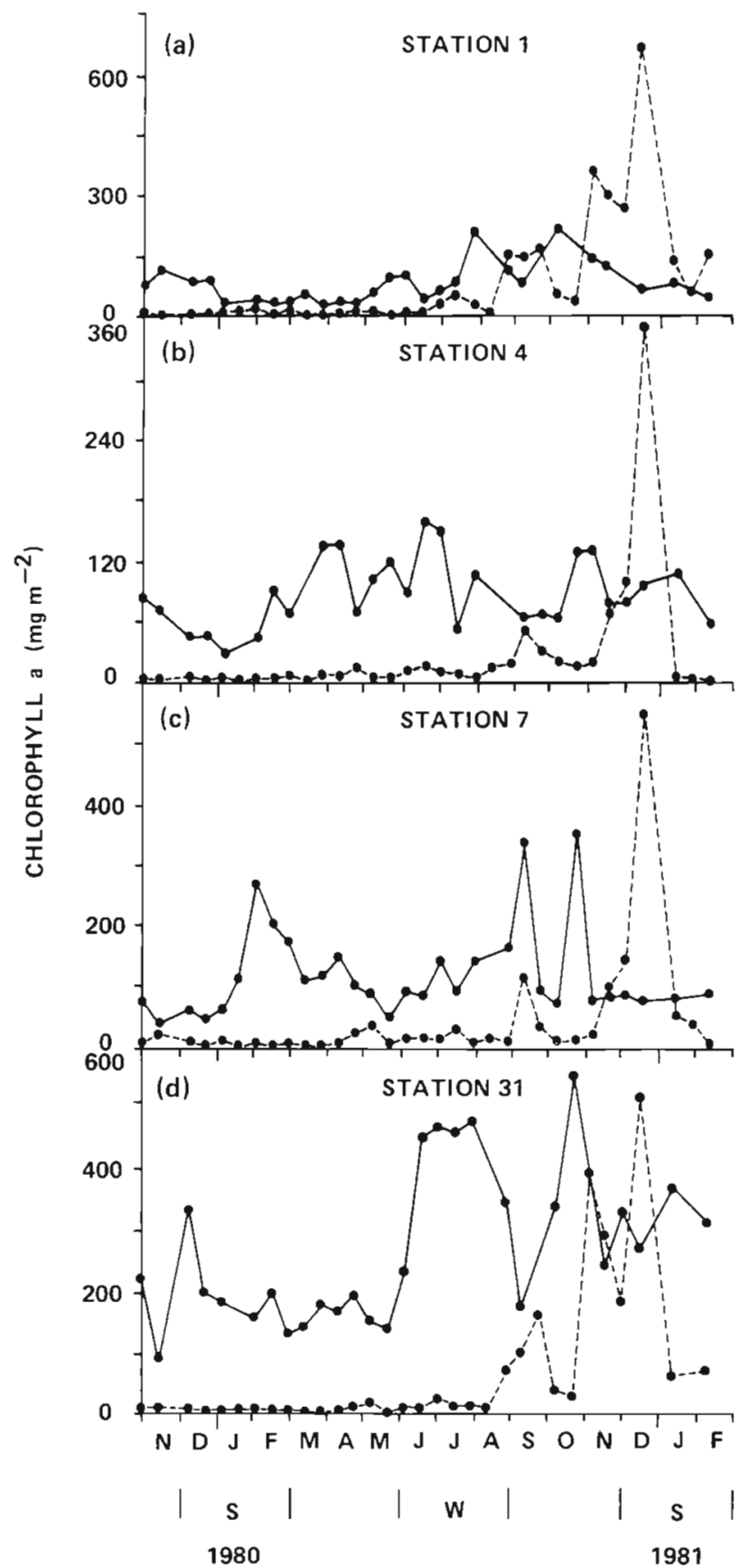

Fig. 4. Seasonal fluctuations in sediment and water column chlorophyll concentration (sediment $=$ solid line). S: summer W: winter

concentration in late autumn was probably a response to nutrient input via river-flow, and the small response by the phytoplankton may have been due to the rapid transfer of the phosphorus from the water column to the sediment. When sediment is resuspended into the water column it will adsorb phosphate if the water column concentration is above the equilibrium point concentration, which for Harvey Estuary sediment is about $5 \mu \mathrm{g} \mathrm{P} \mathrm{l}^{-1}$ (Gabrielson 1981). The winter-early spring diatom bloom was preceded by large flows and nutrient input. Light limitation, as a result of the large diatom biomass, probably brought about the collapse of the sediment bloom. The second peak in sediment chlorophyll concentration, following the collapse of the phytoplankton (diatom) bloom, was probably due to the germination of Nodularia akinetes, which have been observed germinating in the surface sediments. The significance of the sediment akinetes in providing the inoculum for the rapid onset of Nodularia blooms has been discussed by Huber (1984). With the establishment of the planktonic stage of the Nodularia bloom the sediment chlorophyll concentration fell. Secchi disc depth rarely exceeds $30 \mathrm{~cm}$ during the Nodularia bloom and light was probably limiting sediment microalgal biomass.

Marked seasonal fluctuations in sediment chlorophyll concentration were also observed at $\operatorname{Stn} 7$ in Peel Inlet. The major difference between this site and those in the Harvey was the mid-summer peak in sediment chlorophyll concentration. There was no evidence of the germination of Nodularia akinetes in the surface sediments at either of the Peel sites, and substantial populations of Nodularia were found in Peel Inlet about 2 to $3 \mathrm{wk}$ after the onset of the bloom in the Harvey. Most of the Nodularia in the Peel originates in the Harvey, and is tidally flushed into Peel Inlet. At the other Peel site (Stn 4) there was little evidence of seasonal fluctuations in sediment chlorophyll concentration.

Most other studies in which seasonal changes have been encountered have reported an almost ubiquitous low winter, high summer biomass which correlates with the seasonal irradiance curve, with its winter minimum and summer maximum. In the Peel-Harvey system peak biomass occurred in winter/spring. The observed seasonal fluctuations appear to be largely controlled by nutrient availability coupled with light, both of which are mediated through changes in the water column. Grazing pressure may also exert an important influence on seasonal fluctuations. Harpacticoid copepods and amphipods (Corophium minor and Paracorophium excuvatum) are abundant at times in the Peel-Harvey system. However, no benthic meiofaunal studies have been carried out in the system, and the importance of grazing pressure remains to be assessed.

The chlorophyll concentration in the top $1 \mathrm{~cm}$ of surface sediment, at all sites, far exceeded the chlorophyll concentration in the water column above, except during the Nodularia bloom. With the exception of the winter-spring diatom bloom and the following Nodularia bloom most of the observed phytoplankton was in fact benthic diatoms suspended in the water 
column as a result of wind-induced sediment resuspension. Water column chlorophyll a concentration has been shown to be significantly correlated $(p<0.01)$ with the maximum wind speed measured in the $12 \mathrm{~h}$ prior to sampling (Lukatelich \& McComb 1981)

The benthic microalgal community in the system is mainly (>95\%) comprised of diatoms. Common genera were Achnanthes, Amphora, Navicula, Nitzschia, Pleurosigma and Synedra. Other common benthic microalgae were the blue-greens Oscillatoria, which forms a dense mat on the surface sediment at some shallow sites, and Synechococcus.

\section{Site differences}

The mean sediment chlorophyll concentration and the characteristics of the surface sediment at each of the 4 regular sampling sites are shown in Table 3 . Stn 1 dominate. This does not appear to be the case in the Peel-Harvey system. Wind-induced sediment resuspension rates in the Peel-Harvey system are relatively high compared to shallow systems elsewhere, but Stn 4 has a much lower sediment resuspension rate than the other sites (Gabrielson \& Lukatelich 1985).

There appears to be no obvious relation between mean sediment chlorophyll concentration and the nutrient content of the surface sediment. These results support the conclusions of the grid surveys that the sediment type and depth of water above the sediment surface are more important in determining the biomass and distribution of sediment chlorophyll in the PeelHarvey system. Although the spatial distribution of biomass at a particular time does not appear to be determined by nutrient availability, seasonal fluctuations in biomass at a particular site can be explained by changes in nutrient loading and alterations in light penetration through the water column.

Table 3. Sediment characteristics of the regular sampling sites. Mean (range). Sediment nutrient data from Gabrielson (1981)

\begin{tabular}{|c|c|c|c|c|c|c|}
\hline Station & $\begin{array}{l}\text { Water depth } \\
\text { (m) }\end{array}$ & $\begin{array}{c}\text { Water content } \\
(\%)\end{array}$ & $\begin{array}{c}\text { Organic matter } \\
\text { content }(\%)\end{array}$ & $\begin{array}{l}\text { Total phos- } \\
\text { phorus }\left(\mathrm{g} \mathrm{m}^{-2}\right)\end{array}$ & $\begin{array}{l}\text { Total nitrogen } \\
\qquad\left(\mathrm{g} \mathrm{m}^{-2}\right)\end{array}$ & $\begin{array}{c}\text { Chlorophyll a } \\
\left(\mathrm{mg} \mathrm{m}^{-2}\right)\end{array}$ \\
\hline $\begin{array}{c}1 \\
(n=21)\end{array}$ & 2.16 & $\begin{array}{c}62.3 \\
(59.0-66.7)\end{array}$ & $\begin{array}{c}13.4 \\
(10.4-17.6)\end{array}$ & $\begin{array}{c}1.08 \\
(0.6-1.76)\end{array}$ & $\begin{array}{c}11.02 \\
(2.87-15.95)\end{array}$ & 81.5 \\
\hline $\begin{array}{c}4 \\
(n=22)\end{array}$ & 1.86 & $\begin{array}{c}43.9 \\
(33.3-75.4)\end{array}$ & $\begin{array}{c}5.8 \\
(3.0-20.3)\end{array}$ & $\begin{array}{c}1.05 \\
(0.55-4.08)\end{array}$ & $\begin{array}{c}9.49 \\
(2.48-43.72)\end{array}$ & 89.0 \\
\hline $\begin{array}{c}\quad 7 \\
(n=20)\end{array}$ & 2.28 & $\begin{array}{c}42.0 \\
(36.7-48.7)\end{array}$ & $\begin{array}{c}5.5 \\
(4.1-6.5)\end{array}$ & $\begin{array}{c}1.20 \\
(0.79-2.13)\end{array}$ & $\begin{array}{c}10.88 \\
(6.81-14.34)\end{array}$ & 123.4 \\
\hline $\begin{array}{c}31 \\
(n=8)\end{array}$ & 1.47 & $\begin{array}{c}37.8 \\
(24.2-42.2)\end{array}$ & $\begin{array}{c}4.7 \\
(1.7-6.2)\end{array}$ & $\begin{array}{c}1.18 \\
(1.10-1.99)\end{array}$ & $\begin{array}{c}9.26 \\
(7.55-13.65)\end{array}$ & 270.6 \\
\hline
\end{tabular}

had the lowest mean concentration and the concentration at $\operatorname{Stn} 4$ was only slightly higher. The sediment at these sites had the highest organic and water contents. Stn 31 had the lowest organic and water content and had by far the highest mean sediment chlorophyll concentration. The sediment at Stn 7 had a slightly higher organic and water content than Stn 31 but the mean sediment chlorophyll concentration was much lower. This was probably due to the difference in water depth at the 2 sites. Str 31 being much shallower (Table 3).

Several authors (e.g. Moss \& Round 1967, Hickman \& Round 1970, van den Hoek et al. 1979) have found benthic microalgal biomass to be associated with the degree of shelter (physical disturbance) at a particular site. Van den Hoek et al. (1979) found that relatively exposed sites in the Wadden Sea, which are dominated by epipsammic diatoms, have lower standing crops than more sheltered sites where epipelic diatoms

\section{Comparison with other areas}

Data on benthic microalgal biomass from intertidal and shallow coastal areas around the world are presented in Table 4 . The results from the present study fall within the range observed, although the mean concentration at Stn 31 was higher than any of the others reported. Most other studies have been carried out at very different latitudes, with much colder climates which may limit benthic microalgal biomass during winter. Also most other studies have been carried out on intertidal mudflats where abiotic factors may restrict the biomass of benthic microalgae because the cells are continually being suspended and removed by tidal currents (Baille \& Welsh 1980). Windinduced sediment resuspension rates are high in the Peel-Harvey system (Gabrielson \& Lukatelich 1985), but due to the small tidal range there is little transport of benthic microalgae from the system. 
Table 4. Comparison of chlorophyll a concentration of surface sediment from various localities

\begin{tabular}{|c|c|c|c|}
\hline Source & $\begin{array}{l}\text { Locality } \\
\text { (Lat.) }\end{array}$ & $\begin{array}{l}\text { Chlorophyll } \\
\mathrm{mg} \mathrm{m}^{-2}\end{array}$ & $\begin{array}{l}\text { Sediment thickness } \\
\mathrm{cm}\end{array}$ \\
\hline Sanders et al. (1962) & Barnstable Harbor, USA & $147-770$ & 1.0 \\
\hline Fenchel \& Straarup (1971) & Oresund, Denmark (56 $\left.{ }^{\circ} \mathrm{N}\right)$ & $\begin{aligned} 7-19 & \text { (exposed site) } \\
50-93 & \text { (semi-exposed site) }\end{aligned}$ & $\begin{array}{l}1.0-2.0 \\
1.0-2.0\end{array}$ \\
\hline Cadée \& Hegeman (1974) & Western Dutch Wadden Sea & $35-435(\bar{x}=120)$ & 1.0 \\
\hline Matheke \& Horner (1974) & $\begin{array}{l}\text { Chukchi Sea, Alaska, USA } \\
\left(71^{\circ} \mathrm{N}\right)\end{array}$ & $35-321$ & 1.0 \\
\hline Colijn (1978) & $\begin{array}{l}\text { Eastern Dutch Wadden Sea } \\
\left(53^{\circ} \mathrm{N}\right)\end{array}$ & $\begin{array}{l}10-80 \quad(1975) \\
10-400(1976)\end{array}$ & $\begin{array}{l}0.5 \\
0.5\end{array}$ \\
\hline Colijn \& Nienhuis (1978) & German Wadden Sea $\left(53^{\circ} \mathrm{N}\right)$ & $0-100(\bar{x}=40)$ & 0.5 \\
\hline Sorsa (1979) & $\begin{array}{l}\text { Lake Suomunjarvi, } \\
\text { Finland }\left(63^{\circ} \mathrm{N}\right)(2 \text { sites })\end{array}$ & $1975 \begin{array}{l}\bar{x}=70.6(6-301) \\
\bar{x}=158(20-404) \\
\bar{x}=115(12-406) \\
\bar{x}=138(19-406)\end{array}$ & $\begin{array}{l}\text { Unknown } \\
\text { Unknown } \\
\text { Unknown } \\
\text { Unknown }\end{array}$ \\
\hline Colijn \& Dijkema (1981) & Dutch Wadden Sea $\left(53^{\circ} N\right)$ & $\overline{\mathbf{x}}=65$ & 2.0 \\
\hline Davis \& McIntire (1983) & $\begin{array}{l}\text { Netarts Bay, Oregon, USA } \\
\left(45^{\circ} \mathrm{N}\right)\end{array}$ & $\begin{array}{l}\bar{x}=46 \text { (sand site) } \\
\bar{x}=75(\text { fine sand site) } \\
\bar{x}=94(\text { silt site) }\end{array}$ & $\begin{array}{l}1.0 \\
1.0 \\
1.0\end{array}$ \\
\hline Colijn \& de Jonge (1984) & $\begin{array}{l}\text { Eems-Dollard Estuary }\left(53^{\circ} \mathrm{N}\right) \\
\text { (6 sites) }\end{array}$ & $\begin{array}{l}\bar{x}=49 \\
\bar{x}=33 \\
\bar{x}=42 \\
\bar{x}=40 \\
\bar{x}=77 \\
\bar{x}=184\end{array}$ & $\begin{array}{l}0.5 \\
0.5 \\
0.5 \\
0.5 \\
0.5 \\
0.5\end{array}$ \\
\hline This study & $\begin{array}{l}\text { Peel-Harvey estuarine } \\
\text { system }\left(32^{\circ} \mathrm{S}\right)\end{array}$ & $\begin{array}{l}\text { Stn } 1 \bar{x}=81 \quad(27-219) \\
\text { Stn } 4 \bar{x}=89 \quad(31-161) \\
\text { Stn } 7 \bar{x}=123(43-341) \\
\text { Stn } 31 \bar{x}=271(90-558)\end{array}$ & $\begin{array}{l}1.0 \\
1.0 \\
1.0 \\
1.0\end{array}$ \\
\hline
\end{tabular}

Table 5. Water column and sediment chlorophyll a content (tonnes) of the Peel-Harvey system

\begin{tabular}{|lrrrrrr|}
\hline & \multicolumn{2}{c}{ March 1979 } & \multicolumn{3}{c|}{ September 1979} \\
& Peel & Harvey Total & \multicolumn{2}{c|}{ Peel } & Harvey & Total \\
\hline Water & 0.25 & 0.29 & 0.54 & 0.21 & 0.26 & 0.47 \\
Sediment & 8.26 & 13.77 & 22.04 & 10.32 & 9.52 & 19.84 \\
& & & & & & \\
\hline
\end{tabular}

\section{Significance of the benthic microalgae}

The water column and sediment chlorophyll content of the Peel and Harvey estuaries was determined for each of the grid surveys (Table 5). The top $1 \mathrm{~cm}$ of sediment contained on average approximately 40 times the chlorophyll load of the water column above on both occasions. The seasonal data (Fig. 4) also show that, except for a few occasions during the winter diatom bloom and the following Nodulariabloom, the sediment chlorophyll load far exceeds that in the water column. Production rates have not yet been measured for this system, but will clearly be important in determining observed benthic microalgal biomass. Nevertheless, it is clear that the benthic microalgae may contribute a significant fraction of the total production in the Peel-Harvey system, even in years with large planktonic microalgal blooms. In years such as 1979, with below average rainfall, runoff and hence nutrient input, the production of the benthic microalgae may well exceed that of the phytoplankton. Various authors (Cadée \& Hegeman 1974, 1977, Colijn 1978, Davis \& McIntire 1983, Colijn \& de Jonge 1984) have found a significant positive correlation between sediment chlorophyll a concentration and primary production. Using the relation between annual production ( $\left.\mathrm{P}, \mathrm{gC}^{-2}\right)$, assumed to be net production by the authors, and sediment chlorophyll concentration ( $\mathrm{S}$, mg $\mathrm{m}^{-2}$ ) derived by Colijn \& de Jonge (1984) for the Ems-Dollard Estuary, $P=1.24 \mathrm{~S}+13.91(\mathrm{r}=0.9973, \mathrm{n}$ $=6, \mathrm{p}<0.001$ ), the annual production of benthic microalgae in the Peel-Harvey system may exceed 20,000 tonnes of carbon.

Benthic macroalgae are the most important primary 
producers in Peel Inlet, but are almost absent from Harvey Estuary and in years with below average rainfall, the benthic microalgae may well prove to be the most important primary producers in Harvey Estuary.

Acknowledgements. This research, as part of a study of the Peel-Harvey Estuarine System, was supported by funds made available through the Department of Conservation and Environment, Western Australia, and a Commonwealth Postgraduate Research Award held by one of the authors (R. J. L.).

\section{LITERATURE CITED}

Admiraal, W (1980). Experiments on the ecology of benthic diatoms in the Eems-Dollard Estuary. Publ. en Vers!. 3: $1-125$

Anonymous (1971). Standard methods for the examination of water and wastewater. 13th ed. American Public Health Association, Water Pollution Control Federation, American Water Works Publication, Washington D. C.

Baille, P. W. Welsh, B. L. (1980). The effect of tidal resuspension on the distribution of intertidal epipelic algae in an estuary. Estuar. coast. mar Sci. 10: 165-180

Birch, P. B. (1982). Phosphorus export from coastal plain drainage into the Peel-Harvey Estuarine System of Western Australia. Aust. J. mar. Freshwat. Res. 33: 23-32

Bunt, J. S., Lee C. C., Lee, E. (1972). Primary productivity and related data from tropical and subtropical marine sediments. Mar. Biol. 16: 28-36

Cadée, G. C. (1980). Reappraisal of the production and import of organic carbon in the western Wadden Sea. Neth. J. Sea Res. 14: 305-322

Cadée, G. C., Hegeman, J. (1974). Primary production of the benthic microflora living on tidal flats in the Dutch Wadden Sea. Neth. J. Sea Res. 8: 260-291

Cadée, G. C., Hegeman, J. (1977). Distribution of primary production of the benthic microflora and accumulation of organic matter on a tidal flat area, Balgzand, Dutch Wadden Sea. Neth. J Sea Res. 11: 24-41

Colijn, F. (1978). Primary productivity measurements in the Ems-Dollard Estuary during 1975 and 1976. Biologish Onderzoek Eems-Dollard Estuarium, Publ. en Vers. 1 $1-14$

Colijn, F., Dijkema, K. S. (1981). Species composition of benthic diatoms and distribution of chlorophyll $a$ on an intertidal flat in the Dutch Wadden Sea. Mar Ecol. Prog. Ser 4: 9-23

Colijn, F., de Jonge, V N. (1984). Primary production of microphytobenthos in the Ems-Dollard Estuary. Mar. Ecol Prog. Ser. 14: 185-196

Colijn, F., Nienhuis, H. (1978). The intertidal microphytobenthos of the Hohe Weg shallows in the German Wadden Sea. Forschungsstelle Insel- und Küstenschutz Norderney Jahresbericht 29: 149-174

Dal Pont, G. K., Hogan, M., Newell, B. (1974). Laboratory techniques in marine chemistry II - a manual. CSIRO Australia, Div. Fish. Oceanogr., Rep. No. 55

Davis, M. W., Lee, H., II. (1983). Recolonization of sedimentassociated microalgae and effects of estuarine infauna on microalgal production. Mar Ecol. Prog. Ser 11: 227-232

Davis, M W., McIntire, C. D. (1983). Effects of physical gradients on the production dynamics of sediment-associated algae. Mar. Ecol. Prog. Ser 13: 103-114
Dougenik, J. A., Sheehan, P. E. (1977). SYMAP user's reference manual. 5th ed. Laboratory for Computer Graphics and Spatial Analysis, Harvard University, Cambridge, Massachusetts

Estrada, M., Valiela, I., Teal, J. M. (1974). Concentration and distribution of chlorophyll in fertilized plots in a Massachusetts salt marsh. J. exp. mar. Biol. Ecol. 14: $47-56$

Fenchel, T., Straarup, B. (1971). Vertical distribution of photosynthetic pigments and the penetration of light in marine sediments. Oikos 22: 172-182

Gabrielson, J. O. (1981). The sediment contribution to nutrient cycling in the Peel-Harvey Estuarine System. Bulletin No. 96, Dept. of Conserv, and Environ., Perth, Western Australia

Gabrielson, J. O., Lukatelich, R. J. (1985). Wind-related resuspension of sediments in the Peel-Harvey Estuarine System. Estuar coast. Shelf Sci. 20: 135-145

Gargas, E. (1970). Measurements of primary production, dark fixation and vertical distribution of the microbenthic algae in the Oresund. Ophelia 8: 231-253

Gomoiu, M. T. (1967). Some quantitative data on light penetration in sediments. Helgoländer wiss. Meeresunters. 15 $120-127$

Gordon, D. M., Birch, P. B., McComb, A. J. (1981). The ecology of Cladophora in the Peel-Harvey Estuarine System. Bulletin No. 91, Dept. of Conserv. and Environ., Perth, Western Australia

Grøntved, J. (1960). On the productivity of microbenthos and phytoplankton in some Danish fjords. Meddr Danm. Fisk.Og Havunders; N. S. 3: 55-92

Grontved, J. (1962). Preliminary report on the productivity of microbenthos and phytoplankton in the Danish Wadden Sea. Meddr Danm. Fisk.-Og Havunders; N. S. 3: 347-378

Grøntved, J. (1965). Productivity of the microbenthic vegetation in the Danish Wadden Sea (Abstract). Veröff. Inst. Meeresforsch. Bremerhaven, Sonderband 2: 275-276

Gruendling, G. K. (1971). Ecology of the epipelic algal communities in Marion Lake, British Columbia, J. Phycol. 7: 239-249

Hargrave, B. T. (1969). Epibenthic algal production and community respiration in the sediments of Lake Marion. J. Fish. Res. Bd Can. 26: 2003-2026

Heffernan, J. J., Gibson, R. A. (1983). Chlorophyll distribution in continental shelf sediments off West Palm Beach, Florida and West End, Bahamas. Estuar coast. Shelf Sci. 17: $107-110$

Hickman, M. (1974). Effects of the discharge of thermal effluent from a power station on Lake Wabamun, Alberta, Canada - the epipelic and epipsammic algal communities. Hydrobiologia 45: 199-217

Hickman, M., Round, F. E. (1970). Primary production and standing crops of epipsammic and epipelic algae. Br phycol. J. 5: 247-255

Hodgkin, E. P., Birch, P. B., Black, R. E., Humphries, R. B. (1981). The Peel-Harvey Estuarine System study (1976-1980). Report No. 9, Dept. of Conserv and Environ., Perth, Western Australia

Hodgkin, E. P., Lenanton, R. C. (1981). Estuaries and coastal lagoons of South Western Australia. In: Neilson, B. J, Cronin, L. E. (ed.) Estuaries and nutrients. Humana Press, New Jersey, p. 307-321

Hoek, C. van den, Admiraal, W., Colijn, F., de Jonge, V. N. (1979). The role of algae and segrasses in the ecosystem of the Wadden Sea: a review. In: Wolff, W. J. (ed,) Flora and vegetation of the Wadden Sea. Report 3 of the Wadden Sea working group, Texel, The Netherlands, p. 9-118 
Huber, A. L. (1984). Nodularia (Cyanobacteriaceae) akinetes in the sediments of the Peel-Harvey Estuary, Western Australia: potential inoculum source for Nodularia blooms. Appl environ. Microbiol. 47: 234-238

Hunding, C. (1971). Production of benthic microalgae in the littoral zone of a eutrophic lake. Oikos 22: 289-397

Joint, I. R. (1978). Microbial production of an estuarine mudflat. Estuar coast. mar. Sci. 7: 185-195

Leach, J. H. (1970). Epibenthic algal production in an intertidal mudflat. Limnol. Oceanogr. 15: 514-521

Lukatelich, R. J., McComb, A. J. (1981). The control of phytoplankton populations in the Peel-Harvey Estuarine System. Bulletin No. 93, Dept of Conserv. and Environ., Perth. Western Australia

Major, G. A., Dal Pont, G. K., Kyle, J., Newell, B. (1972). Laboratory techniques in marine chemistry - a manual. CSIRO Australia, Div. Fish. Oceanogr., Rep. No. 51

Matheke, G. E. M., Horner, R. (1974). Primary productivity of the benthic microalgae in the Chukchi Sea near Barrow, Alaska. J. Fish. Res. Bd Can. 31: 1779-1786

McComb, A. J. (1982). The effect of land use in catchments on aquatic systems: a case study from Western Australia. Bull. Aust. Soc. Limnol. 9: 1-24

McComb, A. J., Atkins, R. P., Birch, P. B., Gordon, D. M., Lukatelich, R. J. (1981). Eutrophication in the Peel-Harvey Estuarine System, Western Australia. In: Neilson, B. J., Cronin, L. E. (ed.) Estuaries and nutrients. Humana Press, New Jersey, p. 323-342

McGlynn, J. A. (1974). Examination of waters: evaluation of methods for selected characteristics. Australian Water Resources Council, Technical Paper No. 8, Aust. Govt. Pub. Ser., Canberra

Moss, B., Round, F. E. (1967). Observations on standing crops of epipelic and epipsammic algal communities in Shear Water, Wilts. Br Phycol. Bull. 3: 241-248
Nie, N. H., Jenkins, G. H., Steinbrenner, K., Bent, D. H. (1975). Statistical package for the social sciences. 2nd ed. McGraw-Hill, New York

Pamatmat, M. M. (1968). Ecology and metabolism of a benthic community on an intertidal sandflat. Int. Revue ges. Hydrobiol. 53: 211-298

Riznyk, R. Z., Phinney, H. K. (1972). Manometric assessment of interstitial microalgae production in two estuarine sediments. Oecologia (Berl.) 10: 193-203

Riznyk, R. Z., Edens, J. I., Libby, R. C. (1978). Production of epibenthic diatoms in a Southern California impounded estuary. J. Phycol. 14: 273-279

Round, F. E. (1960). Studies on bottom-living algae in some lakes of the English lake district IV. The seasonal cycles of the Bacillariphyceae. J. Ecol. 48: 529-547

Sanders, H. L., Goudsmit, E. L., Mills, E. L., Hampson, G. E. (1962). A study of the intertidal fauna of Barnstable Harbor, Massachusetts. Limnol. Oceanogr. 7: 63-79

Sorsa, K. (1979). Primary production of epipelic algae in Lake Suomunjarvi, Finnish North Karelia. Ann. Bot. Fenn. 16: 351-366

Steele, J. H., Baird, I. E. (1968). Production ecology of a sandy beach. Linol. Oceanogr. 13: 14-25

Strickland, J. D. H., Parsons, T R. (1972). A practical handbook of seawater analysis. 2nd ed. Bull. Fish. Res. Bd Can. 167

Taasen, P., Hoisaeter, T. (1981). The shallow-water soft-bottom benthos in Lindaspollene, Western Norway. 4. Benthic marine diatoms, seasonal density fluctuations. Sarsia 66: 293-316

Whitney, D. E., Darley, W. M. (1979). A method for the determination of chlorophyll $a$ in samples containing degradation products. Limnol. Oceanogr. 24: 183-186

This paper was submitted to the editor; it was accepted for printing on September 9, 1985 